Knowledge and Identity: A Review

*YingFei Gao and Michael Riley

* Address for correspondence: Faculty of Management and Law, University of Surrey, Guildford, GU2 7XH + 44 (0)1483682121 y.heliot@surrey.ac.uk 


\title{
Knowledge and Identity: A Review
}

\begin{abstract}
This paper reviews the literature in a number of areas that converge upon the theme of the role of knowledge within professional identity. Within knowledge transfer literature the individual perspective is underdeveloped and this paper seeks to contribute by exploring the function of knowledge within an individual's professional identity thus unfolding a theoretical connection between the literatures of knowledge and identity. Its central argument concurs with Szulanski's notion of 'internal stickiness' as a barrier to knowledge transfer but extends this hypothesis into the psychological ownership of knowledge and to the idea of 'possessiveness'. The paper argues that the value of self-categorised knowledge places the latter within the individual's cognitive structure of their identity. It offers up the idea of valued knowledge to the knowledge transfer domain and suggests that feelings of possessiveness towards knowledge may intervene in the willingness of an individual to disclose knowledge in a knowledge transfer process.
\end{abstract}




\section{Introduction}

Our review maps a route through the domains of knowledge and identity with the purpose of contributing an explanation of the phenomenon, often referred to as 'stickiness', in which the flow of knowledge in an exchange process is inhibited. It focuses on the individual psychological perspective of knowledge and its innate relationship to identity, that is, how the meaning of knowledge relates to the interpretation of the cognitive sense of self. Such meanings, when activated, may offer a profound explanatory power to behaviours in the process of knowledge transfer. We pick up on Szulanski's (1996) notion of 'internal stickiness' because of his concern for barriers to knowledge transfer. We note that whilst he emphasises ambiguity and comprehension as communication uncertainties, he attributes little influence to personal motivation. Following the line taken by Lam (2000), we acknowledge different types of knowledge and the fact that they can be held individually and collectively. We concur with Szulanski that the process of knowledge transfer is not automatic and argue that an explanation may lie in issues surrounding knowledge ownership. Our focus is in short on expert professional knowledge in the context of knowledge transfer.

The journey is complicated but the pathway is clear. Literature in areas that cohere around the themes of the individual within knowledge transfer processes and the role that knowledge plays in relation to identity is reviewed. What emerges from this is that identity affects willingness to transfer knowledge because the individual has psychological ownership. This may induce feelings of possessiveness towards knowledge which, we argue is part of their professional identity; the resultant 
reluctance is, we argue, a source of stickiness. In support of this, some arguments are fundamental.

The first of these, concerns knowledge ownership. Here we trace the theme of the locus of knowledge through the literature of individual-group psychology to uncover how the pluralism of ownership, i.e., that knowledge which can be owned by an individual and by their professional group, is related to the social identity affiliation process (Tajfel 1978). In other words, an individual's feelings about ownership of their knowledge are bound-up with affiliation to their professional group. We infer from this that the individual-group relationship influences the salience of knowledge to identity. This influence, we suggest, occurs when the valuation of knowledge arbitrates the position of the individual on both polar dichotomies.

We see the individual expert as attached to their knowledge through the valuation of that knowledge and similarly attached to their group when that evaluation becomes a favoured attribute of the individual's group affiliation (professional association). There are two cases to be argued. Firstly, if knowledge is placed in a positively valued category within the cognitive structure then it may well be a favoured attribute of group attachment and therefore it is influential to the development of self identity. Secondly, the corpus of knowledge learned through professional training will be placed in a set of categories that may be similar (not identical) between professionals in the field. This creates the possibility of a shared cognitive structure for individual professionals.

The second fundamental argument concerning knowledge ownership is the complication that knowledge can be embedded in practice. The fact that knowledge can be embedded in practice has the effect of emphasising the primacy of the 
individual as the owner of the knowledge and simultaneously highlighting the role of competence in professional identity. In this pathway between knowledge and identity the personal need of the professional for integration in the workplace creates a situation whereby the expert needs to demonstrate professional competence to fulfil the expectations of their colleagues and of the image of the professional body. For example we trust an accountant because we trust the accounting profession.

This paper explores the conceptual overlap and theoretical connections between the literature of identity and that of knowledge. We see these as centred upon the question of the locus of ownership and on the issue of knowledge being embedded in action or practice at an individual level. The view is offered that there is a reciprocal relationship between knowledge and identity in which both the individual psychological perspective and the social identity of the individual matters. From social identity theory (Tajfel 1978) we assume that the professional gains their recognised professional identity from their professional group. Therefore, in summary, we argue that, knowledge has a central place in the cognitive structure of an individual's professional identity. Thus located, this knowledge, we argue, is anchored by a degree of possessiveness which, in turn, affects the individual's willingness to disclose their knowledge in a knowledge transfer process.

In pursuit of our primary purpose of placing knowledge within the cognitive structure of identity we have identified a commonality within the literatures of knowledge and identity. This consists of the conjoining of the individual aspect of knowledge with the self aspect of identity, the ownership aspect of knowledge with the group affiliation and the practical aspect of knowledge with the socialisation aspect of identity. We use psychological ownership of knowledge to extend the 
connections between the literature of knowledge and identity and to explain the willingness behaviour in knowledge transfer process.

This literature review begins with the context of knowledge transfer. This is followed by a sub-section, entitled 'knowledge' which is intended as a platform for the principal exploration of how knowledge relates to identity, sub-section 'identity and knowledge'. The components of this platform are individualism, possessiveness and willingness and it is from this discussion that the main arguments are developed.

\section{Knowledge Transfer: the Context}

This section begins with a brief statement on the importance of knowledge transfer to economic development then we examine the different processes of knowledge transfer by reviewing the contribution of the principal models.

\section{The role of knowledge transfer within development and firm performance}

That knowledge transfer is a key factor in organisation performance is well established in the literature to the extent that it has become an institutionalised concept within economic and technological development (e.g. Drucker 1994; Dayasindhu 2002; Cohen and Levinthal 1990; Osterloh and Frey 2000). It is now accepted as part of industry and academic relations (Tallman, Jenkins, Henry and Pinch 2004). The literature on economic development and strategy is clear in positioning technological clusters and knowledge transfer at the heart of the development process (Nonaka 1991; Nonaka and Takeuchi 1995; Tallman et al. 2004).

The central ideas which link knowledge transfer to development and performance are competitive advantage and strategic alliances. Work on 
organisational outcomes emphasises the effect of alliances on increasing the firm's stock of knowledge (Albert, Ashforth and Dutton 2000; Argote and Ingram 2000; Helfat 2000; Kogut and Zander 1996). It is the social processes of networking and nexus-forming that bring about opportunities to gain knowledge (Argote, Ingram, Levine and Moreland 2000; Ibarra, Kilduff and Tsai 2005). In this respect, attention has been paid to structural aspects such as proximity and clusters (Mansfield 1991; Mansfield 1995; Mansfield and Lee 1996; Nonaka and Takeuchi 1995). However, notwithstanding structural concerns there is an assumption in the alliance-forming process that, putting legal and competitive constraints aside, there is a level of openness to disclosure based on mutual interests (Ashforth 1985; Schneider 1990; West, Smith, Lu and Lawthom 1998). However, the simple assumption that mutual interests guarantees collaboration is an unsafe one.

Both the nature of the knowledge to be transferred and the level of organisational interaction is crucial (Steensma 1996; Mohrman, Gibson and Mohrman 2002). Central to this idea is the development of new relationships and structures. Cavusgil, Calantone and Zhao, 2003, for example, present a set of hypotheses concerning the relationships between inter-firm relationship strength and knowledge transfer which stresses that close relationships enhance the opportunities for people in firms. Davenport and Prusak (1998) reported eight critical success factors for knowledge transfer including effective knowledge measurement, technical architecture, flexible organisational structure, knowledge-friendly culture, clear vision, a performance-based reward system, multi-channel knowledge transfer and senior management support. These external benefits of knowledge transfer require some control of internal processes that transfer and transform knowledge. We note 
that these critical factors are all external to the individual, a position which we challenge.

The processes of knowledge transfer: mechanistic or individual?

The principal literature we address in this section is summarised in Table 1 together with their model emphasis and contribution listed. These models consider the processes of how knowledge is transferred, either mechanistically or individually oriented, focusing on the solution to the process.

In reviewing the principal models we acknowledge that they are variations on the theme of socialisation within a group. However we highlight two themes which express the different objectives and solutions of the model. The first theme places emphasis on the 'mechanistic' aspect of the process of knowledge transfer highlighting structural and variable exogenous to the individual. The second theme goes some way towards incorporating human aspects into the process of knowledge transfer. The review concludes that there is an emphasis on mechanistic solutions to knowledge transfer process and little emphasis on the individual's role within this process. The implication of this emphasis is the problematic view that knowledge transfer is seen as an automatic process. The following discussion analyses and explains the main contributions identified in Table 1. 
Table 1. A summary of process of knowledge transfer models

\begin{tabular}{|c|c|c|c|}
\hline Authors & Model & Emphasis on & Identified \\
\hline Akbar (2003) & $\begin{array}{l}\text { Intra-individual knowledge } \\
\text { transformation }\end{array}$ & $\begin{array}{l}\text { The higher the knowledge level, the } \\
\text { greater is the degree of tacitness }\end{array}$ & $\begin{array}{lr}\text { The critical element } \\
\text { within tacit knowledge } \\
\text { which r generates } \\
\text { creativity r and } \\
\text { innovation }\end{array}$ \\
\hline $\begin{array}{l}\text { Andrews and } \\
\text { Delahaye } \\
(2000)\end{array}$ & The psychosocial filter & $\begin{array}{l}\text { Organisational sharing, three clusters of } \\
\text { psychosocial filters are: } \\
\text { - } \quad \text { Social confidence } \\
\text { - } \quad \text { Perceived credibility } \\
\text { - } \quad \text { Perceived trustworthiness }\end{array}$ & $\begin{array}{l}\text { The term Psychosocial } \\
\text { filter to describe the } \\
\text { factors which appeared } \\
\text { to affect knowledge } \\
\text { importing } \\
\text { knowledge } \\
\text { decisions }\end{array}$ \\
\hline $\begin{array}{l}\text { Ashforth } \\
(2001)\end{array}$ & $\begin{array}{l}\text { Entry Shock to socialisation } \\
\text { process }\end{array}$ & $\begin{array}{l}\text { Four of the critical motives: } \\
\text { - To locate and learn one's role } \\
\text { within the organisational context } \\
\text { (identity) } \\
\text { - To make sense of the situation and } \\
\text { discern a purpose for being there } \\
\text { - To recover a sense of self- } \\
\text { determination (control) } \\
\text { To connect with others, particularly } \\
\text { one's peers (belonging) }\end{array}$ & $\begin{array}{l}\text { Four of the critical } \\
\text { motives that stimulates } \\
\text { the socialisation } \\
\text { process }\end{array}$ \\
\hline
\end{tabular}

\begin{tabular}{|c|c|c|c|}
\hline $\begin{array}{l}\text { Boland, et al. } \\
(2001)\end{array}$ & Schema & $\begin{array}{l}\text { Schema as the mechanism by which } \\
\text { experience of a particular kind of } \\
\text { knowledge representation affects } \\
\text { performance }\end{array}$ & $\begin{array}{l}\text { Schema can influence } \\
\text { creative thinking of the } \\
\text { knowledge transfer } \\
\text { process }\end{array}$ \\
\hline $\begin{array}{l}\text { Grant and } \\
\text { Baden- } \\
\text { Fuller(2000) }\end{array}$ & $\begin{array}{ll}\text { Three Conditions } & \text { of } \\
\text { Knowledge Transfer } & \end{array}$ & $\begin{array}{l}\text { - Transmitter's knowledge must be } \\
\text { capable of being expressed in a } \\
\text { communicable form } \\
\text { - Must be understandable to the } \\
\text { source and the recipient } \\
\text { - Must be capable of aggregation }\end{array}$ & $\begin{array}{l}\text { The capability of } \\
\text { knowledge transfer }\end{array}$ \\
\hline
\end{tabular}

\begin{tabular}{|c|c|c|c|c|}
\hline $\operatorname{Lam}(2000)$ & Social embeddedness & 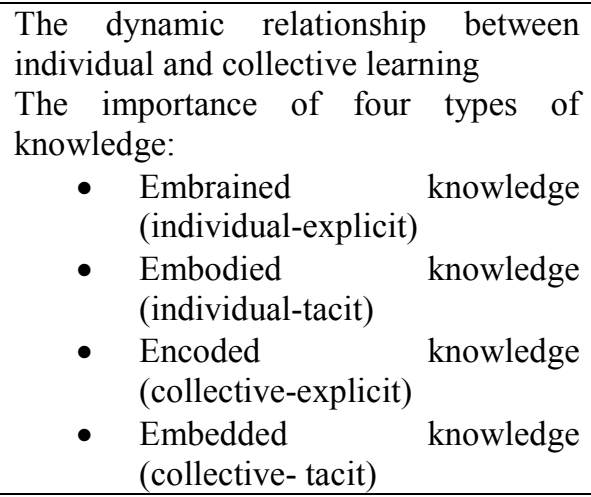 & $\begin{array}{l}\text { The } \\
\text { relationship }\end{array}$ & dynamic \\
\hline $\begin{array}{l}\text { Malhotra } \\
(2003)\end{array}$ & & $\begin{array}{l}\text { The importance of knowledge of } \\
\text { personal connections and relationships; }\end{array}$ & $\begin{array}{l}\text { Individual } \\
\text { knowledge }\end{array}$ & $\begin{array}{r}\text { held } \\
\text { and }\end{array}$ \\
\hline
\end{tabular}


individual held knowledge can be effectively used in combination with the experience of working together as a team

\begin{tabular}{llll}
\hline Authors & Model & Emphasis on & Identified \\
\hline Nonaka, et al. & The SECI Process & A continuous and dynamic interaction & Knowledge transfer as \\
$(2001) ;$ & (Socialisation, & between tacit and explicit knowledge & a highly social process \\
Nonaka & Externalisation, & & \\
$(1991) ;$ & Internalisation and & & \\
Nonaka, & Combination) & & \\
$(1994) ;$ & & & \\
Nonaka and & & & \\
Tacheuchi & & & \\
$(1995)$ & & &
\end{tabular}

\begin{tabular}{|c|c|c|c|}
\hline $\begin{array}{l}\text { O’Dell and } \\
\text { Grayson } \\
(1998)\end{array}$ & $\begin{array}{l}\text { Steps in the Knowledge } \\
\text { Transfer Process }\end{array}$ & $\begin{array}{l}\text { Creating, identifying, collecting, and } \\
\text { organising the best practices and } \\
\text { internal knowledge }\end{array}$ & $\begin{array}{l}\text { Difficulties in early } \\
\text { stages of knowledge } \\
\text { transfer }\end{array}$ \\
\hline $\begin{array}{l}\text { O’Dell and } \\
\text { Grayson } \\
(1998)\end{array}$ & Best practice transfer & $\begin{array}{l}\text { Culture, technology, infrastructure and } \\
\text { measurement are the significant enabler } \\
\text { in the process of knowledge transfer. }\end{array}$ & $\begin{array}{l}\text { The enabler in the } \\
\text { process of knowledge } \\
\text { transfer }\end{array}$ \\
\hline $\begin{array}{l}\text { Szulanski } \\
\text { (1996) }\end{array}$ & $\begin{array}{l}\text { Key barriers of knowledge } \\
\text { transfer }\end{array}$ & $\begin{array}{ll}\text { - } & \text { Ignorance } \\
\text { - } & \text { Absorptive capacity } \\
\text { - } & \text { Lack of pre-existing relationship } \\
\text { - } & \text { Lack of motivation }\end{array}$ & $\begin{array}{l}\text { The barrier of } \\
\text { knowledge transfer had } \\
\text { to do with casual } \\
\text { ambiguity (=vagueness, } \\
\text { doubt) }\end{array}$ \\
\hline $\begin{array}{l}\text { Szulanski } \\
(2000)\end{array}$ & $\begin{array}{l}\text { The basic elements of a } \\
\text { transfer }\end{array}$ & $\begin{array}{ll}- & \text { Source } \\
\text { - } & \text { Channel } \\
\text { - } & \text { Message } \\
\text { - } & \text { Recipient } \\
\text { - } & \text { Context }\end{array}$ & $\begin{array}{l}\text { The basic elements of a } \\
\text { transfer }\end{array}$ \\
\hline
\end{tabular}

\begin{tabular}{|c|c|c|c|}
\hline $\begin{array}{l}\text { Szulanski } \\
(2000)\end{array}$ & Four-phase process & $\begin{array}{ll}\text { - } & \text { Initiation stickiness } \\
\text { - } & \text { Implementation stickiness } \\
\text { - } & \text { Ramp-up stickiness } \\
\text { - } & \text { Integration stickiness } \\
\end{array}$ & $\begin{array}{l}\text { Four types of stickiness } \\
\text { of knowledge }\end{array}$ \\
\hline $\begin{array}{l}\text { Nonaka and } \\
\text { Yamanouchi } \\
\text { (1989) }\end{array}$ & & Metaphor leads to effective transfer & $\begin{array}{lr}\text { Effectiveness } & \text { in } \\
\text { capturing } & \text { and } \\
\text { conveying } & \text { image } \\
\text { amounts of data } \\
\text { information and ideas. }\end{array}$ \\
\hline $\begin{array}{l}\text { Von Krogh, et } \\
\text { al. }(2000)\end{array}$ & Four types of interaction & $\begin{array}{l}\text { - } \text { Originating (sharing tacit } \\
\text { knowledge between individuals) } \\
\text { - Conversing (having group } \\
\text { conversations to form concepts) } \\
\text { Documenting (converting } \\
\text { knowledge into explicit forms) } \\
\text { Internalising (making explicit } \\
\text { knowledge tacit once more) }\end{array}$ & $\begin{array}{l}\text { The natural interactions } \\
\text { among different levels } \\
\text { will expand the entire } \\
\text { knowledge creation } \\
\text { process }\end{array}$ \\
\hline Weick (1995) & $\begin{array}{l}\text { Seven properties } \\
\text { sensemaking }\end{array}$ & $\begin{array}{l}\text { The beliefs of individuals and their } \\
\text { social units mutually influence each } \\
\text { other }\end{array}$ & $\begin{array}{l}\text { Seven properties of } \\
\text { Sensemaking }\end{array}$ \\
\hline
\end{tabular}


The first theme concerns the structural determinants of socialisation processes that encourage knowledge transfer (Nonaka 1991; Nonaka 1994; Nonaka and Tacheuchi 1995; Lam 2000; Nonaka et al. 2001). The model of Socialisation, Externalisation, Combination, and Internalisation (SECI) (Nonaka and Takeuchi 1995 ) is concerned with transforming knowledge through interaction and by practice within the organisation and emphasises learning and continuous innovation. Here the focus is on culture, communication and interaction within groups and how this encourages knowledge exchange, sharing and consequently development and learning.

The same structural and interactional approach inhabits best practice models. O'Dell and Grayson (1998) offer a best practice of knowledge transfer model including a specific set of enabler and steps which are closely related to organisational structure. Lam (2000) and Von Krogh et al. (2000) show a dynamic social relationship between and within groups and suggests the importance of social embeddedness. However, the issue of the form in which knowledge is communicable is part of the structural argument. For knowledge to be shared or exchanged it has to be in a form that is understandable to all parties (Nonaka and Yamanouchi 1989; Grant and Baden-Fuller 2000; Malhotra 2003). Andrews and Delahaye (2000) introduce psychology into the process with their idea of a 'psychosocial filter'. However, this filter is related to socialisation and the communication process.

The second theme moves towards human factors which determine effectiveness in the knowledge transfer process (Szulanski 1996, 2000; Ashforth 2001; Akbar 2003). The work of Szulanski (1996, 2000) examines communication and includes variables such as source, channel, message, recipient and context. The 
latter focuses on the analysis of key barriers to knowledge transfer and identified four types of stickiness of knowledge. These are to an extent passive and unintended barriers. The emphasis here is on the limits of communication and motivation. He coins the term 'internal stickiness', meaning to become fearful of losing ownership and thus become unwilling to support the transfer, and with connotations of reluctance by the recipient to envisage change. Ashforth (2001) identifies the critical motives in knowledge transfer processes including the elements of identity, sense making, self control and sense of belonging, concluding such motives stimulate the socialisation process. The work of Akbar (2003) shows the higher the knowledge level, the greater is the degree of tacitness between individuals which puts emphasis on the learning aspects of socialisation. The implication here is that cooperation between experts is based on assumptions about the extent of mutual knowledge.

What the above analysis shows is that the current literature sees knowledge transfer as a socialisation phenomenon and seeks explanations through the structural determinants of communication and motivation. From this analysis we identify the problem that the individual as a psychological entity has been overlooked in the process. Our intention is to extend Szulanski's idea that reluctance exists within the process and that requires explanation. In order to do this we have adopted an intraindividual perspective. In other words, we bring the individual as a psychological entity into the knowledge transfer process and argue that knowledge and identity intervene in this process.

\section{Knowledge}

From the review of the knowledge transfer literature we argue that the individual perspective has been neglected, therefore it is from this perspective that we now 
examine aspects of knowledge. The central argument concerns how knowledge is psychologically owned by the individual. In this respect we evoke the notion of possession and go on to argue that this property can have an effect on willingness to disclose their knowledge. To this end this section explores three themes related to knowledge. The first is concerned with the internalisation of knowledge. The second theme explores the notion of possessiveness, and the third theme deals with the effect of internalisation and possessiveness on willingness to disclose. The purpose of exploring these themes from the individual perspective is that internalisation and possessiveness will later be shown to connect knowledge to identity, whilst willingness to disclose will be shown to be an intervening factor in knowledge transfer.

In asserting the primacy of the individual in the knowledge transfer process it is necessary to clarify what we mean by the individual perspective. Here we make two distinctions. The first is between our focus on the intra-individual perspective and, what the 'knowledge governance' movement refers to as the 'micro level' (Foss 2007; Rothaermal and Hess 2007). The second is a concern to distinguish related concepts of knowledge learned and validated by experience and socially constructed knowledge because the distinction may influence the locus of knowledge. As our basic proposition is concerned to place knowledge within a cognitive structure we see knowledge as an intrinsic component of the individual. This contrasts with the knowledge governance movement which gets close to the individual, in as far as seeing individuals as being part of micro-processes which can be governed and incentivised, but which remains, in its present state of evolution, as an exogenous approach. Knowledge governance is not yet directly concerned with the psychology of the individual; it is concerned with motivation not motives. Our approach goes 
further, to explain the psychology of the individual by uncovering a reluctance within the knowledge transfer process.

\section{Knowledge and individualism}

The perspective of the individual as the prime locus of knowledge is contested terrain. Cook and Brown (1999), for example, argue that the individual locus of knowledge has been too influential and is dangerous to an integrated approach, an argument that is reversed by Van de Ven and Johnson (2006) and supported by Felin and Hesterly (2007). In asserting the primacy of the individual we are not denying the social constructivist argument that knowledge is a social phenomenon that is different from the aggregation of individuals (Nahapiet and Ghoshal 1998, 246). Nor do we dispute the collectivist view that knowledge can be held within a group (Halbwach 1992). Indeed we will show that this dichotomy is central to arguments concerning the meaning of professional knowledge.

Our stance that the individual perspective is important to the understanding of knowledge transfer is based on three premises. The first of these is that knowledge embedded in action and beliefs reciprocate each other. The term practice implies both action and belief. This means that learning through doing is applying prior knowledge or beliefs. Following the line of Dewey (1986) that knowledge is context specific, practical knowledge can be seen both as the 'understanding' that emerges from direct engagement with the environment and from the applied prior knowledge based on theoretical and scientific knowledge (Kondrat 1992). Philosophical pragmatism sees knowledge as having an instrumental value which places it at the centre of the 'truth process' and simultaneously connects it to action. In this philosophical approach prior beliefs become 'true' when confronted by events and 
reality. Here confronting information in the external environment means completing some action in a specific context. It is by doing this that the individual validates their existing beliefs and, as information is transformed into knowledge, simultaneously gains explanations that might constitute new knowledge (Morton 2003). It is this reinforcing nature of action and belief which validates knowledge through its own instrumental effectiveness and grants primacy to the atomised individual as the agent of knowledge (Tourinho and Neno 2003).

It also draws the external locus of knowledge into the individual's world through the process of engaging with the environment. In other words, knowing is having experienced the transformation of information into knowledge (Polanyi 1964, 1975; Machlup and Mansfield 1983; Kolb 1984; Newell et al. 2002; Orlikowski 2002). This dual nature of knowledge as something both internal and external is captured and operationalised by Simon's concept of bounded rationality where inner psychology meets the outer environment (Simon 1999). The notion of internalised knowledge derived from external enactment enables individuals not just to act effectively but to imagine possible actions (Maturana and Varela 1987; Von Krogh and Roos 1995).

We suggest that the notions of practice and effectiveness brings forms of knowledge together and enhances awareness and appreciation of the value of existing knowledge and we see this as a tentative connection with the idea of professional competence. In other words, valuing knowledge is part of a process which binds professional practice with professional identity.

The second premise concerning knowledge and individualism is the argument that knowledge can be intrinsic to a person. Bernstein (2000) argues that knowing is personal, but only when it is internalised. Therefore we suggest that knowing places 
knowledge not just within the individual self, but also within the realm of that individual's self-identity. This raises the question of how and why this should be the case. Bernstein puts forward an alternative idea which challenges the statement that knowledge is personal and owned. He states that knowledge is money and should flow like money to wherever it can create advantage and profit, for knowledge is separated from persons, their commitments and their personal dedications. These become impediments and restrictions on the flow of knowledge. Moving knowledge about should not be more difficult than moving and regulating money. In other words, he is arguing that any possessiveness associated with the inner value of knowledge is an impediment to its greater purpose. This orientation represents a fundamental break in the relation between the knower and what is known. However, it does not separate knowledge from the individual. For Bernstein, knowledge was an outer expression of an inner relationship. The inner relationship was a guarantee of the legitimacy, integrity, worthiness and value of the knowledge. Intrinsically valuing knowledge can itself produce tensions within the individual in terms of application and continuous renewal. Innate knowledge produces outward behaviour. This view offers a 'rope-bridge' between the cognitive structure, in which knowledge is formed into categories, and the behaviour that follows from that categorisation. It may offer a profound explanatory power in understanding firstly, what the cognitive knowledge held by professionals in terms of categorising themselves professionally is, and secondly what the behavioural effects placed upon them are.

The final premise takes us back to the division of labour and the interdependence of technological processes. In simple terms, the fact of working with others carries the assumption of a degree of commonality of knowledge. Common knowledge, however, is not a prerequisite of cooperation within a group. This is the 
terrain of the knowledge management literature which sees the flow of knowledge as essential to effectiveness within organisations (Karreman and Alvesson 2004). However, the previously quoted evidence that knowledge can be a 'sticky' asset, meaning that it flows between locations with some difficulty is problematic (Szulanski 1996; Von Hippel 1994). The conclusion that there must be impediments is unavoidable. To an extent, this problem can be seen either as one of codification, the impediment being the variety of taxonomies generated (Tsoukas 1996 in Orlikowski 2002), or, as one of structural support design (Kelloway and Barling 2000). However, these may not be the sole sources of the problem.

While common knowledge may not be a perquisite of cooperation, knowledge which specifically enables people to function interdependently is. It gives this particular form of knowledge a value both to the individual and the organisation. The value placed on this knowledge may well be related to both cooperation and the formation of a situated social identity. In other words, knowledge may remain individual but have the function of engaging with others and it is valued for that reason.

\section{Knowledge and the notion of possessiveness}

In the arguments which follow it is possible to suggest that the psychological ownership of knowledge can be strong enough to amount to possession (Pierce, Kostova and Dirks 2001). We argue that, if we are correct, possessions and possessiveness are part of the process of identity formation.

Furby (1991) offered the thesis that there is a 'psychology of mine' which conceptualises ownership as entailing an association between a person and an object. This association leads to the valuation of a possession playing a dominant role in the 
owner's identity to the extent that they become part of the extended self (Belk 1988; Dittmar 1992). Mann (1991, 211) wrote, "What I own feels like a part of me" whereas Sartre $(1969,591-592)$ noted that "to have is one of the three categories of human existence" and that "the totality of my possessions reflects the totality of my being ...I am what I have... what is mine is myself". And yet possessions are secured in a special place labelled 'mine' (Kline and France 1899). Rudmin (1993, 55) wrote: “"Mine' is a small word. It is deceptive in its power and importance. It controls our behaviour, but we rarely notice". These arguments indicate that possessiveness is an intrinsic process that partially determines one's self identity. This intrinsic value of possessions grants to the individual both a sense of continuity across time and security e.g. like a much loved old jacket (Steiner 1978; Pierce, Kostova and Dirks 2003). The meaning of possessions however, is not just an intrinsic attachment. They are visible and communicable and can be ascribed a meaning by society (Kron 1983; McCracken 1986; Saunders 1990; Dittmar 1992). They communicate the individual's identity to others, thus achieving recognition and social prestige, and are therefore symbols of self (Cooper 1976).

Two aspects of possession have an important effect on their relationship to identity. Firstly, they represent an aspect of self-control and secondly, they are, by their very nature, favoured. Furby (1978) argues that individuals feel more control over their possessions than other aspects of life. Possession may be one manifestation of 'effectance motivation', in that the possessor has the ability to affect and control the object in whatever way they wish. Formanek (1991) takes a different line. He argues that the accumulation of possessions produces a positive and uplifting effect. The more you have of something you like, the better you feel. Possibly as a result of this self-enhancing bias, owned objects appear to be more attractive and rated more 
favourably than objects that are not owned (Nuttin 1987; Beggan 1992). It is this aspect of favouritism towards the possession that we argue is salient to identity because it is reflected in a concept which is central to social identity formation, i.e. attachment or sense of belonging. And it is this relationship that connects knowledge to identity.

Notwithstanding the above arguments on possessions and identity, the most important issue is whether knowledge can be regarded as a psychological possession. Our arguments here are tentative owing to lack of empirical support but we give weight to the argument of Bernstein (2000) that knowledge can be internalised. Our assumption is therefore that to be internalised the knowledge has, in some way, to be valued and, that if valued, it can be regarded as a psychological possession which forms an inner meaning to one self. One possible value that can be placed on knowledge is that of utility, that it is valued for its usefulness. The concept of usefulness grants to knowledge an instrumental purpose; something has to be achieved. The achievement can be an action, a thought or both but, in either case, the knowledge has a value. It can be a practical goal, or exploration of something theoretical, or even an abstract concept (Scribner 1986). Usefulness as a value relates to a possession's role in providing necessary functions (Prentice 1987; Dittmar 1992). It could be argued, for example, that some forms of knowledge are valued for their symbolic status which may have the function of distinguishing 'insiders from outsiders'. Similarly, knowledge can be a reminder to an individual of their group affiliation (Collins 2004). The principle we evoke here is that to understand if and how knowledge is possessed we must understand if and how it is valued. This will show how it is being used and provide a connection between knowledge and identity. 
Returning to the 'stickiness' proposition; we argue that psychologically possessed knowledge can be a barrier to knowledge transfer. Dirks, Cummings and Pierce (1996) indicated that psychological ownership explains the conditions under which, individuals both promote and resist change but they did not extend the argument as far as establishing a barrier. We argue that, when professionals, hold their expert knowledge as a self-categorised possession it becomes part of their professional identity. Such 'possession' may evoke possessiveness behaviour which will, in turn, intervene in the level of willingness to disclose and transfer their knowledge.

\section{Knowledge and willingness}

The literature on willingness is limited and has a problem with its definition because it is often taken for granted. In its simplest form willingness can be conceived as a freedom from reluctance (Kahn 1990; May, Gilson and Harter 2004). However, it is not uncommon for the concept simply to be subsumed within the attitude/behaviour prediction relationship as intentionality (see for example Aryee, Chay and Chew 1996; Gallucci and Perugini 2003; Landau, Shamir and Arthur 1992; Lee 2001; Morgan, Miller and Arasaratnam 2003; Stilwell, Liden, Parsons and Deconinck 1998). Putting aside the limitations of definitions, we argue that there are two aspects to the willingness relationship to knowledge. Firstly, there is the willingness to be part of the knowledge transfer process and secondly, the actual willingness to disclose and exchange knowledge. Willingness to participate does not guarantee the latter. Both aspects of willingness are influenced by the level of social identification with collective action and by reciprocity. 
Kelly and Breinlinger (1996) argue that a willingness to participate in collective action might be better understood as an aspect of identification with particular groups. The willingness of individuals to engage in collective action by a group is seen as a measure of their identification with that group (Fosh 1993; Kelly and Kelly 1994). This approach makes group functioning dependent on trust. Whilst this is important, the issue of reciprocity is more immediate to the knowledge transfer process. Molm (1994) suggests that a structure of reciprocal dependence is a defining characteristic of all social relations based on exchange. Fehr, Fischbacher and Gächter (2002) provide compelling evidence which indicates that many people can have a tendency to voluntarily cooperate if treated fairly. They call this behavioural propensity 'strong reciprocity'. Empirically it can lead to an almost universal cooperation in circumstances in which pure cooperation is found, i.e. in circumstances in which there is only completely self-interested behaviour, which might otherwise cause a complete breakdown of co-operation. This view is supported by Goh (2002), who argues that cooperation and collaboration are the dimensions which are critical to knowledge transfer. For example, knowledge transfer requires the willingness of the individual to work with others and disclose knowledge to their mutual benefit. This implies that knowledge transfer will not occur in an organisation unless employees and groups have a natural tendency to share and collaborate with each other. This natural tendency is termed as 'propensity to reciprocity' it intervenes between identity and actual behaviour (Gallucci and Perugini 2003). In summary, both the dependence-on-trust case and the promise of reciprocal action case are part of the individual-group dichotomy. Whilst this argument locates the influences on willingness in the individual-group context and suggests reciprocity as a process, it is not complete. There is a clear need for empirical research on the determinants of 
willingness to disclose once the individual is willing to participate. The knowledge transfer literature infers that once people are willingly inside the process that they will exchange knowledge; we contest this assumption.

\section{Identity and Knowledge}

In this section we show a number of cognitive and the sociological routes that relate knowledge to identity. We build these relationships into a conceptual framework in order to illustrate how they intervene in the process of knowledge transfer. In the previous discussion we have put forward three ideas which, we argue, form a basis for relating knowledge to identity. The ideas are individualism, the notion of knowledge being possessed and the possibility that possessiveness can intervene in willingness. We suggest it is the individual internalised role of knowledge and identity which intervene the process of knowledge transfer. We argue that knowledge has a place in the individual's cognitive identity structure and consequently a role in identity formation. From this we go on to show that the maintenance and enhancement of knowledge is a social process involving group attachment procured through identity formation processes. These assertions are based on four premises.

- Premise 1: That knowledge is part of the self-categorisation process; the way an individual locates themselves within their cognitive social world is influenced by the self-valuation of their knowledge.

- Premise 2: That knowledge is held and categorised as a social construct through group affiliation.

- Premise 3: That knowledge is embedded within action; applied knowledge may even be unconscious because it is contained within action. It can however be demonstrated as competence. 
- Premise 4: Bringing together the second and third premise; there is a process in which awareness of identity is activated when confronted with knowledge embedded in a situation.

In brief, the analysis of these premises needs both a social psychological and a sociological perspective. From a social psychological perspective the theoretical foundation of identity formation and function lies in identity theory (Burke 1980; Burke and Reitzes 1981; Burke and Tully 1977; Stryker 1980; Stryker 1987) with its connotations of self-categorisation theory (Turner 1982; Turner 1985; Turner 1987; Oakes 1987; Oakes, Haslam and Turner 1994; Turner, Oakes, Haslam and McGarty 1994; see also Onorato and Turner 2001) and social identity theory (Tajfel 1978) with its concept of group affiliations. It is this latter theory which provides the theoretical context for relating knowledge to the individual - group relationship. The sociological perspective in contrast gives insight into the formation of identities by its emphasis on the continuous dialogue between self identity and present situation.

\section{Self-identity and self-concept distinguished}

Identity is essentially about self-definition, how one defines oneself and hopes to be defined by others (Gecas 1982). Although it is a representation of the self it needs to be differentiated from the idea of the self-concept which is focussed more on how people seen themselves in terms of personality characteristics. The self-concept is a configuration of perception of the individual's personality and fundamental view of the world; a mental representation of personality (Rogers 1951; Sternberg and Ruzgis 1994). The self-concept is developed in childhood and, after the formative years of life, becomes fairly set and is made less malleable by circumstance. Identity, in contrast, is a self description that allows the individual to place themselves within the 
various worlds they inhabit. The implication of this is that identity can change and that an individual can hold a number of identities simultaneously. However, for an identity to have any meaning (be self-recognised) it has, to an extent, to be stable. Markus and Kunda (1986) make the important point that self identity is both stable and malleable. The stabilising element of this process is the anchoring effect of the categorisation of knowledge.

\section{Self-categorisation and knowledge}

When we argue that knowledge is central to identity we are saying that it has a conscious presence in the cognitive structures of the self and of self identity in particular. This leads directly to questions about where knowledge is placed, and by what process. We argue that the process by which the individual places and locates themselves is one of self-categorisation - sorting life into mental categories. Being an individual is itself a category (Turner 1985; Turner 1987; Turner et al. 1987; Crisp and Hewstone 2006). From this standpoint individuals have levels of abstraction in their cognitive structures which vary in strength and produce relative judgements about themselves. The substance of these categories can be internal aspects of the self such as substantive knowledge (for example, 'I'm good at chemistry') and self knowledge (e.g. 'I'm a slow learner') but it can also be the location of the self within the individual's social environment (e.g. 'I'm middle class'). We argue that the individual's self-valuation of their substantive knowledge would be a dimension which they use to place themselves with their cognitive world in terms of their group affiliations and feelings of self-efficacy (Lang and Lee 2005). In other words, the process uses substantive matter, including own knowledge, to guide the self into a set 
of categories (Turner 1982). Such self-categorisation guides individual behaviour including the direction of group affiliations. Haslam (2004), for example, suggests that self-categorisation as personal categorisation would affect commitment to group participation (e.g. commitment to a knowledge transfer process). This highlights the crucial form of self-categorisation that links it directly to identity, that is, group attachment or affiliation.

Here is the essential dichotomy of identity; that it can be both personal (individualistic categories) and social (group orientated categories). The resolution of this dichotomy, we argue, is part of the identity formation process and more specifically such resolution will be influenced by the way in which the individual is attached to their chosen group.

\section{Individual-group affiliation and attribute valuation}

Social identity theory (Tajfel 1978) argues that people seek part of their self identity through affiliation to groups which they then favour. In the context of professional identity the group is deemed to be the professional body. The key to understanding how the fact of dual ownership of knowledge creates routes towards identity lie in attribute favouritism and shared categorisation. There are four distinct routes, or lines of argument, that relate knowledge to individual-group affiliation and here social psychology and sociology offer different contributions. Firstly, in the case of professional knowledge, the fact that it can be held both by the individual and by the professional group means that the process of social identity is salient. Secondly, the ethnocentric property of social identity theory suggests the terms of group attachment may feature knowledge as a valued and favoured group attribute. Thirdly, the 
argument that knowledge is a social construct normally sits within an organisational context but we extend such arguments to include professional bodies. The key element here is that a corpus of knowledge cannot be remembered by the individual as such but can be remembered collectively. Fourthly, we accept the contribution of the socialisation process in attaching an individual to a group in an organisational context.

Following the line of Tajfel $(1969,1978)$ that cognitive categories are preevaluated entities, it follows that the way an individual categorises their knowledge resolves into an evaluated set of categories. In the case of expert knowledge we assume that it is highly valued knowledge. There are two levels of abstraction here. In one case knowledge itself is a category. If that category is valued then it may well be a favoured attribute of group attachment and therefore it is influential to the development of self identity. In this scenario identity is constructed using knowledge as a valued attribute of a group to which the individual favours. In the second case the corpus of knowledge learned through professional training will be placed in a set of categories that may be similar (not identical) between professionals in the field. In other words, individuals may categorise their knowledge as a salient attribute of their group attachment which creates the possibility of the group having common elements within their cognitive structure of identity as well as a sense of own group favouritism (members could equally well favour other attributes such as prestige).

\section{Collective knowledge and action}

Bounded rationality suggests that knowledge cannot exist in its entirety within the individual's consciousness (Simon 1999). Therefore the question arises as to how does a professional recall the corpus of knowledge they learned to qualify? Halbwach 
(1992) reinforces the arguments made by workplace socialisation processes transferring and transforming knowledge when he argues that it is only through affiliation to groups that an individual can recall knowledge because that knowledge is formed and applied in a specific group context. It is in this sense that memory requires a group dimension. Organisational cognition argues that tacit knowledge is contained within activity systems (work systems and routines) that represent a collective mind in that the system itself only works because of a shared interdependence of knowledge between group members (Spender 1998). The awareness of such knowledge is, according to Weick and Roberts (1993) dependent on the concept of paying heed (mindfulness). But this is disputed by Reber (1993) who points out that much tacit knowledge is unconscious and also is effective. Here Reber is following Polanyi (1964) in that some knowledge is unconsciously known (e.g. how to ride a bike). This notion of tacit knowledge depending on activity with others suggests that knowledge, once outside that system, may not be within the reach of recall. It can only be recalled within a group context. However, irrespective of the notion of interrelated activity, the case for action as a source of knowledge is crucial to the relationship between knowledge and identity. We argue that professional actions contain professional knowledge. Performance of an action embodies knowledge within it. It is this notion that links the wider concept of professional conduct directly to identity.

\section{Socialisation and identity}

Sociological theories of identity formation point to the transitional and sometimes provisional nature of identity. Individuals construct identity from the degree of fit between the current self-identity and the discourse presented by the present situation 
(Schryer and Spoel 2005). Broadly speaking theories focus on organisational and work task influences on one hand, and on social interaction on the other. The processes of transition and change are influenced by organisational socialisation and the requirement of the work task (Downing 2005; Pratt, Rockmann and Kaufman 2006). The emphasis on the nature of the task draws the argument back towards the centrality of knowledge within identity and in the direction of the valuation of knowledge, particularly the utility value. In support of this is the notion that the role of the task is to validate competence. This in turn re-enforces the current identity. By performing a task we validate our knowledge (Wallace 1995).

The social interaction arguments centre upon processes that arbitrate the individual self with the need for a social identity and also upon relational identities (Breakwell 1992). Markus and Kunda (1986) suggest that the need to be seen as similar to others yet unique is an intrinsic dilemma, resolution of which influences the self-concept as well as self identity. The idea that identity can be a function of placement in relation to individuals and to groups is pursued by Sluss and Ashworth (2007). They argue that not only does that add to the multiplicity of possible identities, it also makes the important point that the individual's 'social world view' can alter depending on relational identity. These are arguments in favour of the situation influencing identity but they do not contradict the notion of a more secure cognitive structure for identity. This set of processes can come together in a single process to make the individual aware of the relationship between their knowledge and their professional identity. This single process, we suggest, is the activated identity.

\section{Knowledge and the activated identity}


We argue that identity itself is an active psychological entity. In this respect, we argue for the importance of the process whereby identities are activated by situations and suggest that such situations are interpreted through a set of prior assumptions which are, in part, engendered by group affiliations. Therefore the content and structure of identity becomes engaged with the situation (Endsley 1988). We argue that when this process occurs it is possessed knowledge and its place in identity that will come to the fore.

A sense of professionalism occurs when specialised knowledge is critical to doing the work (Fine 1996). Here the content dimensions of identity structure that are relevant to the situation are brought into play. In this argument elements of the situation make the individual conscious of their own self-identity. The situation 'speaks' directly to the content of the individual's identity. Here there must be some form of recognition of relevance, salience or difference between the content dimensions of self-identity. We argue that the individual's categorised knowledge structure can be activated by the specifics of the situation. For example, for a sports fan (where the sports fan's identity is activated by seeing sport) watching soccer without knowledge of the rules would force comparisons with other games as a means of understanding, but would also, and simultaneously, be verifying their identification with other games and their identity as a sports fan. Although knowledge and group affiliation are involved in the interpretation of the situation in this simplistic example, the strength of these two processes, comparison and verification, would depend on the motivational context (wanting to watch sport). However simply being able to use knowledge to interpret a situation need not engage the identity: the verification process is not automatic. The non-sports fans could be engaged through curiosity and try to develop new knowledge but there would be no 
verification of identity unless the individual identified with a group who 'dislike sport'. The 'fit' process involves knowledge alignment and verification. It also involves motivation but exactly what role motivation plays in the 'fit' process remains unclear. What this example illustrates is that there are two complimentary processes working together. In seeking 'fit' the individual is determining which part of their knowledge structure will be applicable to the situation and simultaneously verifying that they have that knowledge. Consequently, these processes feed back into the individual's sense of professional identity.

At one level there is the issue of the individual proactively wanting to impose on a situation in order to affect it and create a statement about self/identity (Serpe and Stryker 1987). A more common situation would be are where a goal or purpose is contained in the situation requiring a judgement and by this means issues of intentions, choice and value are drawn into the activation process. Here the relevance of the individual professional's knowledge is the activating agent in the situation. Emirbayer and Mische (1998) argue that action is always a complex amalgam of social and interactive phenomenon. The need to make a judgement brings in the processes associated with 'fit' with the situation. The individual needs to feel a sense of security in the rightness of the judgement. This sense of security comes on the one hand from the knowledge basis from which it was made reinforced by their professional identity and on the other hand from the inner meaning of the knowledge that has been valuated and categorised. If, as Coleman (1990) argues, actions are caused by anticipated consequences then the only guide the professional has to estimating those consequences is their accumulated, valued professional knowledge. 


\section{A conceptual framework}

The conceptual framework is built in two stages. The first stage uses the theoretical arguments made above to explain how knowledge is related to group affiliation and thus to identity. The second stage shows how the process by which willingness to transfer knowledge is affected by the individual's professional identity and the place of knowledge within it.

The first stage incorporates the forgoing arguments that connect knowledge to self identity through a set of six processes;

1. self-categorisation by means of knowledge

2. attachment to a group which co-owns the knowledge

3. attachment to that group through knowledge as a valued group attribute

4. the dependence on the group context for recall of knowledge

5. recall of knowledge through professional actions sanctified by the group

6. the need to be socialised into the current situation and to adjust identity to fit in with the professional work group.

The first five processes are cognitive and affective, with the latter being behavioural. Figure 1 illustrates the processes by which knowledge is related to group affiliation. 
Figure 1 Processes relating knowledge to identity through group affiliation

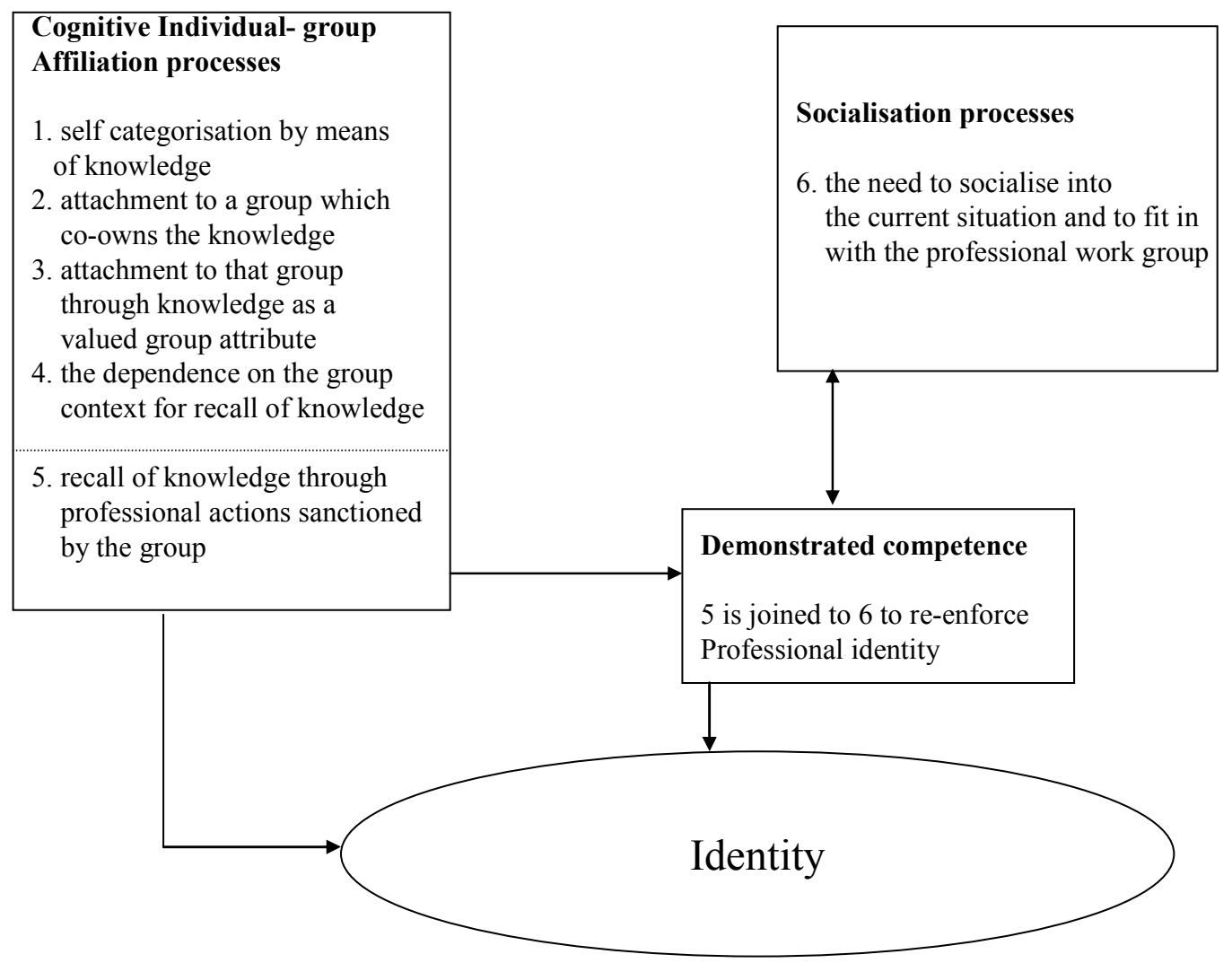

There are two routes; the cognitive and affective route (left side of diagram) and the socialisation process (right side of diagram). Both routes express different processes of group affiliation which conjoin in the concept of identity. The lower box illustrates that the cognitive and the social come together under the banner of demonstrable competence when the group sanctioned knowledge is demonstrated to colleagues, and thus validating the individual's professional status and legitimacy as a group member.

The thrust of our arguments have been to explore theoretical connections between knowledge to identity. The second stage of the conceptual framework, 
illustrated in Figure 2 draws conclusions as to how knowledge and identity relations affect knowledge transfer. Fundamentally our arguments seek to explain the existence of a personal reluctance to exchange knowledge based on individual psychological knowledge ownership and its relationship to group affiliation. This, we argue, influences the willingness of the individual to exchange their knowledge.

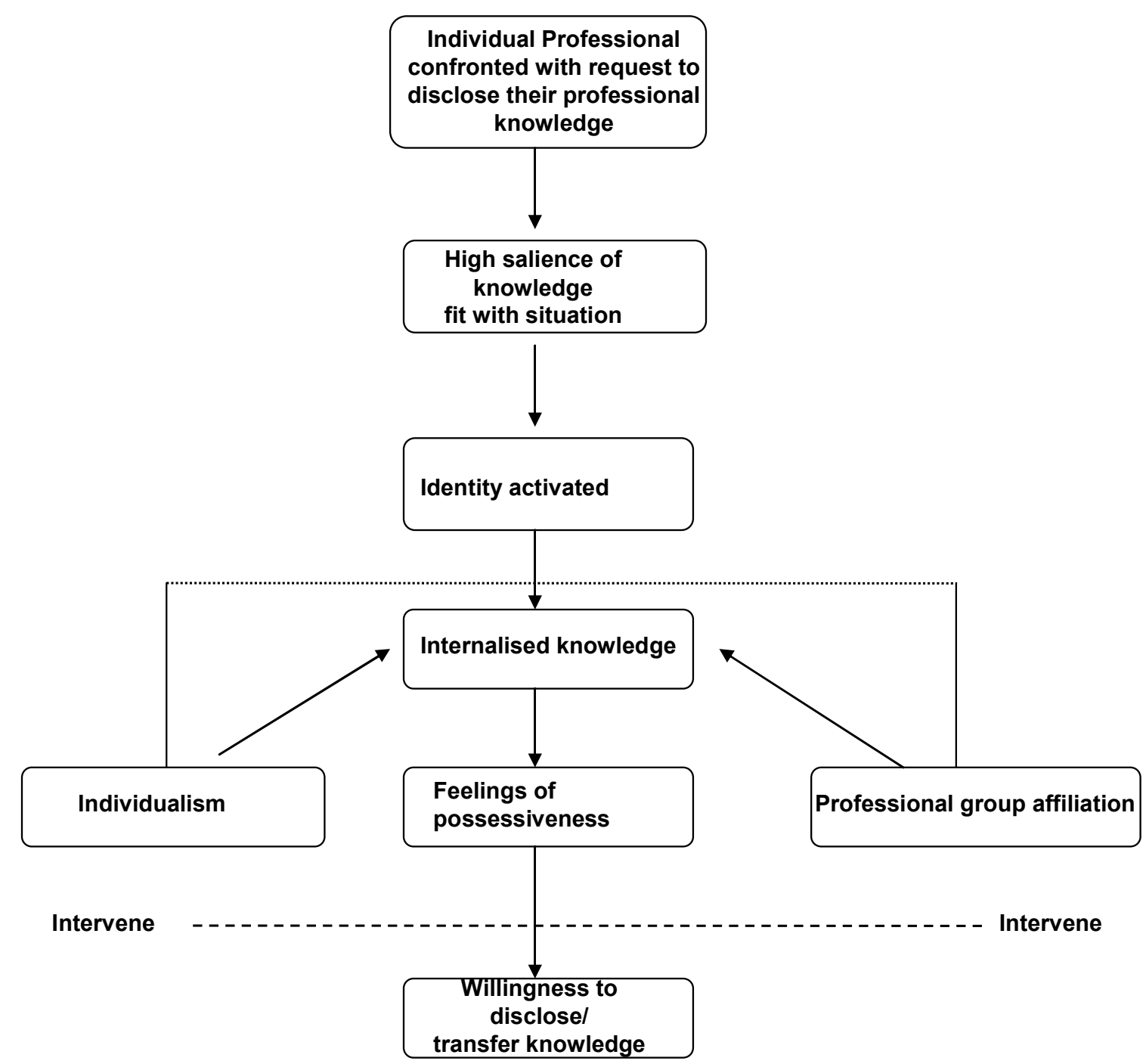

Figure 2 Process from identity to willingness

In Figure 2, we use the expression 'high salience of knowledge' to represent the valuation through internalisation of knowledge. The key element of the conceptual framework is that it is the internalisation of knowledge, valued by 
individuals for whatever reason, which counts. These diagrams show progress from a request to disclose through to the possibility that possessiveness based on knowledge ownership may intervene. The dotted line expresses the innate dichotomy of knowledge ownership between individual and group. The internalisation is about the valuation of knowledge, irrespective of the locus of ownership.

\section{Conclusions}

Our starting point has been the 'stickiness' of knowledge evident in knowledge transfer processes. We have argued a case for the proposition that knowledge has a central place in the cognitive structure of an individual's professional identity. Thus located, this knowledge, we argue, is anchored by a degree of possessiveness which, in turn, affects the individual's willingness to disclose their knowledge in a knowledge transfer process. It is in our view that empirical support is needed for the central plank of this assertion, that is the self-evaluation of knowledge and its relationship to feeling of psychological ownership.

Notwithstanding these concerns we have made a case for the argument that knowledge can be psychologically possessed and have suggested that the valuation of knowledge is central to that idea. We conclude from this that this phenomenon intervenes in the process of willingness to disclose knowledge, which in effect implies that it can promote both positive willingness and reluctance.

This intervention means that the individual has to be conscious of their knowledge and here we draw attention to the nature of practice as having a role in identity. In this respect not only does it embody professional knowledge but it also has the ability to activate the identity that makes it salient to the idea of professional 
identity. If when knowledge is activated it simultaneously makes the individual conscious of the locus of, and value of, that knowledge, then action is connected directly to the nature of identity. Building on this, we suggest, in the context of professional knowledge, that the effectiveness of practice, taking action that works, is reinforcement at the individual level, not just of ability but of a body of professional knowledge.

One of the foundation arguments in support of our conceptual framework is the notion of internalisation. The problem here is that the literature does not firmly connect internalisation of knowledge to identity. The literature is limited as to what internalisation actually means and this aspect needs empirical support if stronger connections are to be made between knowledge and identity. In fact any research agenda on internalisation should be expanded to encompass the role for valuing knowledge. Valuing and evaluation prompts the question of whether different levels of, or valuation of, knowledge mean different levels of identity and differential willingness to disclose knowledge. This in turn may provide some explanatory power to behaviours in the process of knowledge transfer.

The conclusion of the review therefore is that there is a case for the intervention of willingness at the individual level in the knowledge transfer process, and that this is made possible through the conceptual and theoretical integration of two discrete literatures: knowledge and identity. In making this case we have argued that the understanding of knowledge transfer needs to go beyond micro level process to include intra-individual perspectives. 


\section{References}

Akbar, H. (2003). Knowledge levels and their transformation: towards the integration of knowledge creation and individual learning. Journal of Management Studies, 40(8), 1997-2021.

Albert, S., Ashforth, B. E. and Dutton, J. E. (2000). Organizational identity and identification: charting new waters and building new bridges. Academy of Management Review, 25, 13-17.

Andrews, K. and Delahaye, B. (2000). Influences on knowledge processes in organizational learning: the psychosocial filter. Journal of Management Studies, 37(6), 797-810.

Argote, L. and Ingram, P. (2000). Knowledge transfer: a basis for competitive advantage in firms. Organizational Behavior and Human Decision Processes, 82(1), 150-169.

Argote, L., Ingram, P., Levine, J. and Moreland, R. L. (2000). Knowledge transfer in organizations: learning from the experience of others. Organizational Behavior and Human Decision Processes, 82(1), 1-8.

Aryee, S., Chay, Y. W. and Chew, J. (1996). An investigation of the willingness of managerial employment to accept an expatriate assignment. Journal of Organizational Behavior, 17(3), 267-283.

Ashforth, B. E. (2001). Role Transitions in Organisational Life: an Identity-Based Perspective. New Jersey: Lawrence Erlbaum Associates.

Ashforth, B. E. (1985). Climate formation: issues and extensions. Academy of Management Review, 10, 837-847.

Beggan, J. K. (1992). On the social nature of non-social perceptions: the mere ownership effect. Journal of Personality and Social Psychology, 62(2), 229237.

Belk, R. W. (1988). Possessions and the extended self. The Journal of Consumer Research, 15,139-168.

Bernstein, B. (2000). Pedagogy, Symbolic Control and Identity. rev. ed., Lanham: Rowman \& Littlefield.

Boland, R. J., Singh, J., Salipane, P., Aram, J. D. and Fay, S. Y., (2001). Knowledge representations and knowledge transfer. Academy of Management Journal, 44, 393-417.

Breakwell, G. M. (1992). Processes of self-evaluation: efficacy and estrangement. In Breakwell, G. M. Social Psychology of Identity and the Self Concept. London: Surrey University Press.

Burke, P. J. and Reitzes, D. C. (1981). The link between identity and role performance. Social Psychology Quarterly, 44, 83-92. 
Burke, P. J. and Tully, J. (1977). The measurement of role identity. Social Forces, 55, 880-897.

Burke, P. J. (1980). The self: measurement implications from a symbolic interactionist perspective. Social Psychology Quarterly, 43, 18-29.

Cavusgil, S. T., Calantone, R. J. and Zhao, Y. S. (2003). Tacit knowledge transfer and firm innovation capability. Journal of Business and Industrial Marketing, 18 (1), 6-21.

Cohen, W. and Levinthal, D. (1990). Absorptive capacity: a new perspective on learning and innovation. Administrative Science Quarterly, 35(1), 128-152.

Coleman, (1990). Foundations of Social Theory. Cambridge, Mass.: Harvard University Press.

Collins, R. (2004). Interaction Ritual Chains. Princeton, NJ: Princeton University Press.

Cook, S. D. N., and Brown, J. S. (1999). Bridging epistemologies: the generative dance between organizational knowledge and organizational knowing. 10(4), 381-400.

Cooper, C. ed (1976). The House as a Symbol of the Self. New York: Holt, Rinehart \& Winston.

Davenport, T. H. and Prusak, L. (1998). Working Knowledge. Boston: Harvard Business School Press.

Dayasindhu, N. (2002). Embeddeness, knowledge transfer, industry clusters and global competitiveness: a case study of the Indian software industry. Technovation, 22, 551-560.

Dewey, J. (1986). Logic. The Theory of Inquiry. In Boydstone, J.A., ed. John Dewey: the Later Works. 12, 1925-1953, Carbonadale: Southern University Press.

Dirks, K. T., Cummings, L. L. and Pierce, J. L. (1996). Psychological ownership in organizations: conditions under which individuals promote and resist change. In: Woodman, R. W. and Pasmore, W. A. eds., Research in Organizational Change and Development. 9, 1-23. Greenwich, CT: JAI Press.

Downing, S. (2005). The Social Construction of Entrepreneurship: Narrative and Dramatic Processes in the Coproduction of Organizations and Identities. Entrepreneurship Theory and Practice, 185-204.

Drucker, P. F. (1994). The theory of business. Harvard Business Review, September/October, 95-104.

Dittmar, H. (1992). The Social Psychology of Material Possessions: to Have is to Be. New York: St. Martin's Press.

Emirbayer, M. and Mische, A. (1998). What is agency? Academy Journal of Sociology, 103 (4), 962-1023.

Endsley, M (1988). Design and evaluation for situational awareness enhancement. Proceedings of the 32 ${ }^{\text {nd }}$ Annual Meeting of the Human Factors Society, 97-101. 
Fehr, E., Fischbacher, U. and Gächter, S. (2002). Strong reciprocity, human cooperation, and the enforcement of social norms. Human Nature, 13 (1), 1-25.

Felin, T, and Hesterley, W. S. (2007). The knowledge-based view, nested herterogeneity, and the new creation: philosophical considerations on the locus of knowledge. Academy of Management Review, 32 (1), 195-218.

Fine, G. A. (1996). Justifying work: occupational rhetorics as resources in restaurant kitchens. Administrative Science Quarterly, 41 (1), 90-115.

Formanek, R. (1991). Why they collect: collectors reveal their motivations. Journal of Social Behavior and Personality, 6, 275-286.

Fosh, P. (1993). Membership participation in work-place unionism: the possibility of union renewal. British Journal of Industrial Relations, 31, 577-592.

Foss N. J.(2007) The Emerging Knowledge Governance Approach: Cjallenges and Characteristics Organization 14: 29-52

Furby, L. (1991). Understanding the psychology of possession and ownership: a personal memoir and an appraisal of our progress. Journal of Social Behavior and Personality, 6, 457-463.

Furby, L. (1978). Possessions: toward a theory of their meaning and function throughout the life cycle. In: Baltes, P. B. ed., Life Span Development and Behavior. New York: Academic Press, pp. 279-336.

Gallucci, M. and Perugini, M. (2003). Information seeking and reciprocity: a transformational analysis. European Journal of Social Psychology, 33(4), 473495.

Gecas, V. (1982). The self-concept, Annual Review of Sociology, 8, 1-33.

Goh, S. C. (2002). Managing effective knowledge transfer: an integrative framework and some practice implications. Journal of Knowledge Management, 6(1), 2330 .

Grant, R. M. and Baden-Fuller, C. (2000). Knowledge and economic organization: an application to the analysis of interfirm collaboration. In: von Krogh, G., Nonaka, I. and Nishigushi, T. eds., Knowledge Creation: a New Source of Value. London: MacMillan, pp. 89-111.

Halbwach, M. (1992). On Collective Memory. Chicago: University of Chicago Press.

Haslam, A. S. (2004). Psychology in Organizations: the Social Identity Approach, 2nd edition. London: Sage.

Helfat, C. E. (2000). Guest editor's introduction to the special issue: the evolution of firm capabilities. Strategic Management Journal, 21, 955-959.

Ibarra, H., Kilduff, M. and Tsai, W. (2005). Zooming in and out: connecting individuals and collectivities at the frontiers of organizational network research. Organization Science, 16(4), 359-371.

Kahn, W. A. (1990). Psychological conditions of personal engagement and disengagement at work. Academy of Management Journal, 33, 692-724. 
Karreman, D. and Alvesson, M. (2004). Cages in tandem: management control, social identity and identification in a knowledge-intensive firm. Organization, 11(1), 149-175.

Kelly, C. and Breinlinger, S. (1996). The Social Psychology of Collective Action: Identity, Injustice and Gender. London: Taylor \& Francis.

Kelly, C. and Kelly, J. (1994). Who gets involved in collective action? Social psychological determinants of individual participation in trade unions. Human Relations, 47 (1), 63-88.

Kelloway, E. K. and Barling, J. (2000). Knowledge work as organizational behaviour. International Journal of Management Reviews, 2 (3), 287-304.

Kline, L. and France, C. L. (1899). The psychology of mine. Pedagogical Seminary \& Genetic Psychology, 6, 421-470.

Kolb, D. A. (1984). Experiential learning: experience as the source of learning and development, Englewood Cliffs, NJ.: Prentice-Hall

Kogut, B. and Zander, U. (1996). What firms do? coordination, identity, and learning. Organization Science, 7, 502-518.

Kondrat, M. E. (1992). Reclaiming the practical: formal and substantive rationality in social work. Social Service Review, 66(2), 237-255.

Kron, J. (1983). Home-Psych: The Social Psychology of Home and Decoration. New York: Potter.

Landau, J. C., Shamir, B. and Arthur, M. B. (1992). Predictors of willingness to relocate for managerial and professional employees. Journal of Organizational Behavior, 13 (7), 667-680.

Lam, A. (2000). Tacit knowledge, organisational learning and societal institutions: an integrated framework. Organization Studies, 21 (3), 487-513.

Lang, J. C. and Lee, C. H. (2005). Identity accumulation, others' acceptance, jobsearch self-efficacy, and stress. Journal of Organizational Behavior, 26, 293312 .

Lee, H. J. (2001). Willingness and capacity: the determinants of prosocial organizational behaviour among nurses in the UK. International Journal of Human Resource Management, 12(6), 1029 -1048.

Markus, H. and Kunda, Z. (1986). Stability and malleability of the self-concept. Journal of Personality and Social Psychology, 51 (4), 858-866.

Machlup, F. and Mansfield, U. eds., (1983). The study of information: interdisciplinary messages. New York: Wiley.

Malhotra, Y. (2003). Measuring national knowledge assets of a nation: knowledge systems for development (expert background paper). Expanding Public Space for the Development of the Knowledge Society: Report of the Ad Hoc Expert Group Meeting on Knowledge Systems for Development, 4-5 September, Department of Economic and Social Affairs Division for Public Administration and Development Management, United Nations, New York, pp. 68-126. 
Mann, D. W. (1991). Ownership: a pathography of the self. British Journal of Medical Psychology. 64, 211-23.

Mansfield, E. (1991). Academic Research and Industrial Innovation. Research Policy, 20, $1-12$.

Mansfield, E. (1995). Academic Research Underlying Industrial Innovations: Sources, Characteristics, and Finance. The Review of Economics and Statistics, 77, 55-65.

Mansfield, E. and Lee, J-Y. (1996). The modern university: contributor to industrial innovation and recipient of industrial R\&D support. Research Policy, 25, 104758.

Maturana, H., and Varela, F. (1987). The tree of knowledge: the biological roots of human understanding. Boston: Shambhala.

May, D. R., Gilson, R., and Harter, L.M. (2004). The psychological conditions of meaningfulness, safety, and availability and the engagement of the human spirit at work. Journal of Occupational and Organizational Psychology, 77, 11-37.

McCracken, G. (1986). Culture and consumption: a theoretical account of the structure and movement of the cultural meaning of consumer goods. Journal of Consumer Research, 13, 71-84.

Mohrman, S. A., Gibson, C. B. and Mohrman, A., (2002). Doing research that is useful to practice: a model and empirical exploration. Academy of Managerial Journal, 44 (2), 357-375.

Molm, L. D. (1994). Dependence and risk: transforming the structure of social exchange. Social Psychology Quarterly, 57 (3), 163-176.

Morgan, S. E., Miller, J. K. and Arasaratnam, L. A. (2003). Similarities and differences between African Americans' and European Americans' attitudes, knowledge, and willingness to communicate about organ donation. Journal of Applied Social Psychology, 33(4), 693 -715.

Morton, A. (2003). A Guide Through the Theory of Knowledge. Oxford: Blackwell.

Nahapiet, J. and Ghoshal, S. (1998). Social capital, intellectual capital and the organisational advantage. Academy of Management Review, 23 (2), 242-266.

Newell, S., Robertson, M., Scarbrough, H., and Swan, J. (2002). Managing Knowledge Work. New York: Palgrave.

Nonaka, I. (1991). The knowledge-creating company. Harvard Business Review, 69 (6), 96-104.

Nonaka, I. (1994). A dynamic theory of organisational knowledge creation. Organization Science, 5(1), 14-37.

Nonaka, I. and Takeuchi, H. (1995). The Knowledge-Creating Company, New York: Oxford University Press.

Nonaka, I. and Yamanouchi, T. (1989). Managing innovation as a self-renewing process. Journal of Business Venturing, 4, 299-315. 
Nonaka, I., Konno, N., and Toyama, R. (2001). Emergence of 'Ba': a conceptual framework for the continuous and self-transcending process of knowledgecreation. In: Nonaka, I., and Nishiguchi, T., eds., Knowledge Emergence: Social, Technical and Evolutionary, Dimensions of Knowledge Creation, Oxford: Oxford University, pp. 13-29.

Nuttin, J. (1987). Affective consequences of mere ownership: the name letter effect in twelve European languages. European Journal of Social Psychology, 17, 381402.

Oakes, P. J. (1987). The salience of social categories. In J. c. Turner, M.A. Hogg, P. J Oakes, S. D. Reicher, \& M.S. Wehterell (Eds.), Rediscovering the social group: a self-categorization theory (pp. 117-141). London: Blackwell Publishing.

Oakes, P. J. Haslam, S. A., and Turner, J. C. (1994). Stereotyping and social reality. Oxford, UK and Cambridage, MA: Blackwell Publishing.

O’Dell, C. and Grayson, C. J. (1998). If Only We Knew What We Know: The Transfer of Internal Knowledge and Best Practise. New York: The Free Press.

Onorato, R. S., and Turner, J. C. (2001). The "I", "me", and the "us": The psychological group and self-concept maintenance and change. In C. Sedikides and M. B. Brewer (Eds.), Individual self, relational self, collective self (pp.147170). Philadelphia, PA: Psychology Press.

Orlikowski, W. J. (2002). Knowing in Practice: Enacting a Collective Capability in Distributed Organizing. Organization Science, 13(3), 249-273.

Osterloh, M. and Frey, B. S. (2000). Motivation, knowledge transfer, and organizational forms. Organization Science, 11(5), 538-550.

Pierce, J. L., Kostova, T., and Dirks, K. T. (2001). Towards a theory of psychological ownership in organizations. Academy of Management Review, 26, 298-310.

Pierce, J. L., Kostova, T., and Dirks, K. T. (2003). The state of psychological ownership: integrating and extending a century of research. Review of General Psychology, 7(1), 84-107.

Polanyi, M. (1964). Personal knowledge: toward a post-critical philosophy, Chicago: University of Chicago Press.

Polanyi, M. (1975). Personal Knowledge. In: Polanyi, M. and Prosch, H. eds., Meaning, Chicago: University of Chicago, pp. 22-45.

Rogers, C. R. (1951). Client Centered Therapy. Boston: Houghton.

Pratt, M. G., Rockmann, K.W., and Kaufmann, J. B. (2006). Constructing professional identity; the role of work and identity learning cycles in the customization of identity among medical residents. Academy of Management Journal, 49(2), 235-262.

Prentice, D. A. (1987). Psychological correspondence of possessions, attitudes, and values. Journal of Personality and Social Psychology, 53 (December), 9931003 . 
Rothaermel F T, Hess A.M. (2007) Building Dynamic Capabilities: Innovation Driven by Individual-, Firm-, and Network-Level Effects. Organization Science, Nov/Dec2007,. 18: 898-921

Rudmin, F. W. (1993). Property. In: Lonner, W. and Malpass, R. eds., Psychology and Culture, Boston: Allyn and Bacon, pp. 55-58.

Saunders, P. (1990). A Nation of Home Owners. London: Unwin Hyman.

Sartre, J. P. (1969). Being and Nothingness: A Phenomenological Essay on Ontology, New York: Philosophical Library.

Scribner, S. (1986). Thinking in action: some characteristics of practical thought, in Sternberg, R. J. and Wagner, R.K. (eds.), Practical Intelligence: Nature and Origins of Competence in the Everyday World. Cambridge: Cambridge University Press.

Serpe, R. T. and Stryker, S. (1987). The construction of self and reconstruction of social relationships. In: Lawer, E. and Markovsky, B. eds., Advances in Group Processes. Greenwich, CT: JAI, pp. 41-66.

Schneider, B. ed. (1990). Organizational Climate and Culture. Oxford: Jossey-Bass.

Schryer C. F., and Spoel, P. (2005). Genre theory, health-care discourse, and professional identity formation. Journal of Business and Technical Communication, 19, 249-278.

Simon, H.A. (1999). Bounded rationality and organizational learning. Reflections 1 (2), 17- 27.

Sluss, D. M., and Ashforth, B. E. (2007). Relational identity and identification; Defining ourselves through work relationships. Academy of Management Review, 32, 9-32.

Spender, J-C (1998). The Dynamics of Individual and Organizational Knowledge in Eden, C. and Spender, J-C (eds) Managerial and Organizational Cognition. London: Sage, pp.13-39.

Steensma, K. H. (1996). Acquiring technological competencies through interorganisational collaboration: an organisational learning perspective. Journal of Engineering and Technological Management, 12, 267-286.

Sternberg, R. J., and Ruzgis, P. (1994). Personality and intelligence. Cambridge: Cambridge University Press.

Steiner, G. (1978). Martin Heidegger. Chicago: University of Chicago Press.

Stilwell, D., Liden, R., Parsons, C. and Deconinck, J. (1998). Transfer decision making: different decision models depending on the transfer conditions? Journal of Organizational Behavior, 19(6), 539-557.

Stryker, S. (1987). Identity theory: developments and extensions. In: Yardley, K. and Honess, T. eds., Self and Identity: Psychosocial Perspectives. Chichester: John Wiley \& Sons, pp. 89-103.

Szulanski, G. (1996). Exploring internal stickiness: impediments to the transfer of best practice within the firm. Strategic Management Journal, 17 (Special Issue), 27-44. 
Szulanski, G. (2000). The process of knowledge transfer: a diachronic analysis of stickiness. Organizational Behavior \& Human Decision Processes, 82 (1), 9-27.

Tajfel, H. (1969). Cognitive aspect of prejudice. Journal of Social Issues, 25, 79-98.

Tajfel, H. (1978). Interindividual behaviour and Intergroup Behaviour, In: Tajfel, H. ed., Differentiation between Social Groups: Studies in the Social Psychology of Intergroup Relations. London: Academic Press, pp. 27-60.

Tallman, S., Jenkins, M., Henry, N., and Pinch, S. (2004). Knowledge, clusters and competitive advantage. Academy of Management Review, 29 (2), 258-271.

Tourinho, E. Z. and Neno, S. (2003). Effectiveness as truth criterion in behavior Analysis. Behavior and Philosophy, 31, 63-80.

Turner, J. C. (1987). The analysis of social influence. In: Turner, J. C., Hogg, P., Oakes, P., J., Reicher, S. D. and Wetherell, M. S. eds., Rediscovering the Social Group: A Self-Categorization Theory. Oxford: Blackwell, pp. 68-88.

Turner, J. C. (1982). Towards a cognitive redefinition of the social group. In: Tajfel, H. ed., Social Identity and Intergroup Relations. Cambridge: Cambridge University Press, 15-40.

Turner, J. C. (1985). Social categorization and the self-concept: a social cognitive theory of group behaviour. In: Lawler, E. J. ed., Advances in group processes. Greenwich, CT: JAI Press, pp. 77-122.

Turner, J. C., Hogg, M. A., Oakes, P. J., Reicher, S. D. and Wetherell, M. C. (1987). Rediscovering the Social Group: A Self-Categorization Theory. New York: Basil Blackwell.

Turner, J. C., Oakes, P. J., Haslam, S. and McGarty, C. (1994). Self and collective: Cogntition and social context. Personality and Social Psychology Bulletin, 20, 454-463.

Van de Ven, A. H. and Johnson, P.E. (2006). Knowledge for theory and practice. Academy of Management Review, 31(4), 802-821.

Von Hippel, E. (1994). Sticky information and the locus of problem solving: implications for innovation. Management Science, 40 (4), 429-439.

Von Krogh, G. and Roos, J. (1995). A perspective on knowledge, competence and strategy. Personnel Review, 24(3), 56-76.

Von Krogh, G., Ichijo, K. and Nonaka, I. (2000). Enabling Knowledge Creation, Oxford: Oxford University.

Wallace J. E. (1995). Organizational and professional commitment in professional and non-professional organizations. Administrative Science Quarterly, 40, 228255 .

Weick, K. E. (1995). Sensemaking in Organisations. Thousand Oakes: Sage.

Weick K, and Roberts K, H. (1993). Collective mind in organizations: heedful interrelating on flight decks. Administrative Science Quarterly, 38 (3), 357-381. 
West, M. A., Smith, H., Lu, F. W. and Lawthom, R. (1998). Research excellence and departmental climate in British Universities. Journal of Occupational and Organizational Psychology, 71, 261-281. 